\title{
The Analysis of Brand Image and Brand Awareness on Purchase Decisions (Survey of Mayoutfit Bandung Consumers)
}

\author{
Anita Dewi Rachmawati ${ }^{1, *}$ Heny Hendrayati ${ }^{2,}$ Vanessa Gaffar ${ }^{3}$ \\ ${ }^{1}$ Universitas Pendidikan Indonesia \\ ${ }^{2}$ Universitas Pendidikan Indonesia \\ ${ }^{3}$ Universitas Pendidikan Indonesia \\ *Corresponding author. Email: anitadewi.rachma@student.upi.edu
}

\begin{abstract}
The study aims to determine the effect of brand image and brand awareness on purchase decisions on Mayoutfit Bandung's consumers. The population in this study were all Mayoutfit Bandung Consumers. The sampling technique uses a simple random sampling method with a total sampling of 50 people. The measurement scale uses a Likert scale with multiple regression tests using the program application SPSS 16.0 for data analysis. Hypothesis testing using T-test shows that brand image positively affects purchasing decisions of 3,800; a significance value of $0.0000<0.05$, and a regression coefficient of 0.146 . Meanwhile, brand awareness has a positive effect on purchasing decisions of 3.862, a significance value of $0,000<$ 0.005 , and a regression coefficient of 0.606 . Hypothesis testing using the f-test shows that the brand image and brand awareness variables influence purchasing decisions by $21 \%$, with the remaining $79 \%$ influenced by other variables.
\end{abstract}

Keywords: brand image, brand awareness, purchase decisions.

\section{INTRODUCTION}

Fast fashion is a current phenomenon happening in the fashion world right now. It is a modern term for cheap clothing produced quickly by retailers in response to new trends. Since the year 2000, fashion has been metamorphosed into an industry that is fast, updates, and trendy. Brands that have dominated the retail fashion industry could duplicate the display style of home fashion boards and present it at a low price. Brands that include no Zarra, H \& M, Gucci.

Fast fashion is defined as the trend of fashion changing with a fast concept, the concept of ready-towear. Many cheap fast-fashion labels have sprung up in Indonesia. It turns out to triggers consumptive behavior in society. The fast-fashion concept spread quickly because it is cheap and easily obtained by anyone else.

Bandung, as one of the fashion cities in Indonesia, produces various kinds of fashion brands. One of the brands in Bandung, which is being popular, is Mayoutfit. Mayoutfit started its business by opening an online shop. It has already opened a boutique, and they sell a wide range of garments that are mainly its own product, and only about $20 \%$ is taken from other suppliers. Mayoutfit was initiated by four brothers whose hobby is shopping. The name "Mayoutfit" is chosen, referring to May 2013, when it was first released. The offline store of Mayoutfit is located at Gegerkalong Hilir street number 9, Bandung. The products offered focus on women's needs ranging from clothes, handbags, wallets, shoes to accessories. 
One of the factors that affect the customers' purchase decision is the brand image as a reference before purchasing a product or service. This company should be able to create the image of a brand that is attractive and describe the benefits of the products. It should also follow with the wishes and needs of consumers. Thus, consumers have a positive image of the brand. In addition to the brand image, brand awareness also becomes a factor influencing the consumer to purchase. Brand awareness is the ability of consumers to recognize and remember a particular brand. Brand image and brand awareness are expected to increase the popularity of Mayoutfit among its target audience in the city of Bandung. Based on the above phenomena, the study is intended to examine the influence of brand image and brand awareness on the Mayoutfit Bandung customers' purchase decision.

\section{METHODS}

This research is a descriptive study with a quantitative approach. This study aims to determine the effect of brand image and brand awareness on purchasing decisions. The independent variables used are brand image and brand awareness. The dependent variable used is a purchasing decision.

The population used in this study is all Mayoutfit Bandung consumers. The number of samples used in this study was 50 respondents. The sampling method used is probability sampling with simple random sampling. Data collection methods in this study using a questionnaire method through questionnaires. Data collected were analyzed using multiple regression analysis using the SPSS 16.0 program.

\section{RESULT AND DISCUSSION}

Hypothesis testing is done to determine the effect of brand image and brand awareness on purchasing decisions for Mayoutfit products. Multiple regression analysis was chosen to analyze the submission of hypotheses in this study. The following results of multiple regression analysis conducted using the SPSS 16.0 program. Table 1. Show the result of multiple regression analyzes.

Table 1. Summary of the results of multiple regression analyzes

\begin{tabular}{|c|l|l|l|l|}
\hline Variable & Coefficient & t-count & Sig. & Conclusion \\
\hline $\begin{array}{c}\text { Brand } \\
\text { Image }\end{array}$ & .146 & 3,800 & 0,000 & Significant \\
\hline $\begin{array}{c}\text { Brand } \\
\text { Awarness }\end{array}$ & 0,606 & 3,862 & 0,000 & Significant \\
\hline A constant & 28,210 & & \\
\hline Adjusted $\boldsymbol{R}^{2}$ & 0,210 & 7,501 & \\
\hline F-count & - 001 & \\
\hline Sig. & Primary & pta & & \\
\hline
\end{tabular}

Source: Primary data processed
From the results of the regression analysis, it can be seen that the multiple regression equation is as follows:

$$
\begin{gathered}
\mathrm{Y}=28,210+0,146 \text { (Brand Image })+0,606(\text { Brand } \\
\text { Awareness })+\mathrm{e}
\end{gathered}
$$

The T-test is used to test the effect of each independent variable on the dependent variable. Based on table 1 , the results of the t-test statistics for brand image variables obtained a t-test value of 3.800 with a significance value of 0,000 less than 0.05 and the regression coefficient has a positive value of 0.146 , the hypothesis stating "there is a positive influence of brand image to Mayoutfit's product purchase decision "is accepted. Variable brand awareness obtained a t-test value of 3.862 with a significance value of 0.000 less than 0.05 , and the regression coefficient has a positive value of 0.606 then the hypothesis that states "there is a positive effect of brand awareness on purchasing decisions Mayoutfit" is accepted.

The $\mathrm{F}$ test is used to test the effect of the independent variables simultaneously on the dependent variable. Based on table 1 , the F-count value is 7,501 with a significance value of $0.001<0.05$; it can be concluded that there is a significant influence between the brand image variables and brand awareness simultaneously on purchasing decisions.

The coefficient of determination is used to measure the effect of independent variables on the dependent variable. The test results Adjusted R 2 in this study obtained a value of 0.210 . This shows that purchasing decisions are influenced by variable brand image and brand awareness by $21 \%$, and the remaining $79 \%$ are influenced by other factors not included in this study.

Based on this research, brand image influences purchasing decisions. This is consistent with the theory put forward by reference [1] that consumers who have a positive brand image will be more likely to purchase. Reference [2] also stated the importance of developing a brand image in purchasing decisions. Consumers assume that products with well-known brands in the market are better than less popular brands. Well-known products have complete information so consumers can easily distinguish the characteristics of each of these products. Brand awareness also influences consumer purchasing decisions. This indicates that consumers have known the Mayoutfit brand. The brand of a product that is already attached to the consumer's mind will provide added value. When consumers recognize, remember a brand well, and feel they are close enough to the brand, the higher the likelihood that consumers will decide to repurchase the product.

Brand image and brand awareness simultaneously influence purchasing decisions. If the brand image and brand awareness are jointly improved, then the purchasing decision will increase, and vice versa. The 
results of this study support previous research conducted by [3] and [4], which state that brand image and brand awareness have a positive and significant influence on purchasing decisions.

\section{CONCLUSION}

The T-test result showed that purchasing decisions on Mayoutfit Bandung Consumers are influenced by brand image and brand awareness that have a positive effect. Hypothesis testing using the F-test shows that brand image and brand awareness variables influence purchasing decisions by $21 \%$, with the remaining $79 \%$ influenced by other variables.

\section{REFERENCES}

[1] Setiyadi, J. Nugroho, Perilaku konsumen, konsep dan implikasi untuk strategi penelitian pemasaran, Jakarta: Prenada Media, 2003.

[2] Wicaksono, Muhammad, Analisis bauran pemasaran terhadap keputusan pembelian konsumen, Jakarta: Bumi Aksara.

[3] Yanti, O.Z. Merry, and S. Hendri, "Jurnal penelitian pengaruh kesadaran merek, asosiasi merek dan brand image terhadap keputusan pembelian aqua di kecamatan taman sidoarjo," J. Ekonomi., vol. 5 no. 5, 2016.

Dharma, P.S.A. Ngakan, and P.G. Sukaatmadja, "Jurnal penelitian pengaruh citra merek, kesadaran merek, dan kualitas produk terhadap keputusan membeli produk apple," J. Manajemen., vol. 4 no. 10,2015 